\title{
Teologi Misi Bagi Gerakan Misi dan Komunikasi Kristen Pasca Pandemi Covid-19
}

\author{
Jamin Tanhidy \\ Sekolah Tinggi Teologi Simpson Ungaran \\ Email: jamintan92@gmail.com
}

\begin{abstract}
The essence of mission theology in the form of Missio Dei, Missio Christos, and Missio Ecclesiae is the mission of God, in the form of the activity of the Triune God to redeem His creation from destruction due to sin. This theological framework is the basis of thought that underlies the Christian mission and communication movement after the Covid-19 pandemic or the New Normal Era. Therefore, the church is invited to rethink and reconstruct its mission strategy in a non-exclusive, tolerant and holistic way. The research method used is in the form of library studies by examining bible texts, research journals and books related to research topics or titles in order to answer research problems. The results of the study found that the church needs to pay greater attention to global issues of humanity, promote open and construction dialogue with followers of other religions and increase the intensity of the use of social media and virtual communication in conveying and disseminating the gospel message.
\end{abstract}

Key words: Mission Theology, Christian Communication, The Covid-19 Pandemic

\begin{abstract}
Abstrak
Hakekat teologi misi berupa Missio Dei, Missio Christos, dan Missio Ecclesiae adalah misi Allah (God's Mission) berupa aktifitas Allah Tritunggal (The Truine God) menebus dunia ciptaan-Nya dari kebinasaan akibat dosa. Kerangka pemikiran teologis ini menjadi dasar pemikiran yang melandasi gerakan misi dan komunikasi Kristen pasca pandemi Covid-19 atau Era New Normal. Olehnya, gereja diajak untuk memikirkan ulang dan merekonstruksi strategi misinya dengan sikap non-eksklusif, toleran dan melayani secara holistik. Metode penelitian yang dipakai berupa studi perpustakaan dengan mengkaji teks-teks alkitab, jurnal penelitian dan buku-buku yang berkaitan dengan topik atau judul penelitian guna menjawab masalah penelitian. Hasil penelitian menemukan bahwa gereja perlu memberi perhatian yang lebih besar kepada isu-isu global kemanusian, mengalakkan dialog konstruktif dan terbuka dengan penganut agama lain dan meningkatkan intensitas pemanfaatan media sosial dan komunikasi virtual dalam menyampaikan dan menyebarluaskan berita Injil.
\end{abstract}

Kata Kunci: Teologi Misi, Komunikasi Kristen, Pandemi Covid-19

\section{Pendahuluan}

Pandemi Covid-19 yang sedang melanda dunia saat ini, awalnya bersumber dari mutasi virus yang dikenal dengan nama SARS-CoV-2 yang masih serumpun dengan virus SARS yaitu rumpun coronavirus, sejenis virus flu. Dijuluki Corona Viruse Disease 2019 atau Covid-19 karena pertama kali muncul di kota Wuhan China, akhir tahun 2019 silam, kemudian menyebar ke Korea Selatan, Spanyol, Italia, Amerika Serikat dan negara-negara Asia sepanjang tahun 2020 lalu, dan sampai saat ini sudah menyebar ke 185 negara. Jutaan 
jiwa terinfeksi dan menjadi korban keganasan virus ini, disebabkan penyebarannya yang sangat cepat. Tidak heran isu utama yang menjadi perhatian dunia sekarang ini ialah bagaimana mencegah penularan virus ini dan menyelamatkan nyawa para pasien yang tertular. ${ }^{1}$ Penerapan protokol kesehatan yang ketat yang dikumandangkan WHO, baik bagi para petugas kesehatan dan khususnya masyarakat dengan cara mengedepankan pola hidup sehat dengan memakai masker, mencuci tangan atau memakai desinfektan sebagai pelindung, dan menjaga jarak (dikenal dengan istilah Social Distancing), diyakini menjadi syarat utama memutuskan rantai penyebaran Covid-19.

Akibat dari penerapan protokol kesehatan tersebut di atas, terutama menjaga jarak, banyak sekali pabrik dan tempat-tempat pertemuan publik ditutup, sehingga berdampak kepada krisis ekonomi global terparah yang melanda dunia saat ini. Jutaan orang kehilangan pekerjaan di seluruh dunia. Pandemi ini sudah menjadi krisis kemanusian. Seiring dengan penetapan protokol kesehatan di atas, maka masyarakat dunia mengalami perubahan budaya yang bersifat global. . Orang-orang bepergian diwajibkan memakai masker, di tempat-tempat publik di sediakan peralatan mencucui tangan, dan alat test suhu badan (Thermo Gun) serta tempat duduk diberi jarak 1-2 meter guna menerapkan physical distancing. Para ahli menyebutnya sebagai Era New Normal, dalam arti suatu kebiasaan yang tidak lazim (seperti memakai masker dan hand sanitizer serta menjaga jarak), sekarang diadaptasi oleh seluruh masyarakat dunia sebagai suatu kebiasaan baru. Termasuk upaya negara-negara mengantisipasi kehancuran ekonomi dengan menerapkan strategi bekerja di rumah, yang dikenal dengan istilah Work From Home atau WFH. Dalam dunia pendidikan, dikenal dengan belajar di rumah secara online atau pembelajaran daring. Selama pandemi Covid-19, gerejagereja juga sudah melakukan ibadah live streaming di rumah-rumah. ${ }^{2}$ Dalam bidang pengabaran Injil atau penginjilan, telah dilakukan oleh gereja dan lembaga penginjilan dengan memanfaatkan website dan link di berbagai situs media sosial seperti whatsapp, facebook, instagram, YouTube, Zoom, dll. Berkat kemajuan teknologi di bidang telekomukasi dan informasi berpotensi besar bagi masyarakat dunia saat ini melakukan komunikasi visual. Ini merupakan peluang baik bagi misi pengabaran Injil. Tentunya, adaptasi kebiasaan-kebiasaan baru ini menjadi ciri khas dari budaya masyarakat Pasca Pandemi Covid-19. Dapat disimpulkan, pandemi Covid-19 menyebabkan perubahan signifikan baik di bidang sosial, kesehatan, ekonomi, pendidikan dan agama, termasuk cara berkomunikasi secara individu maupun publik.

Berkaitan dengan tugas misi, maka bagaimana gereja seharusnya menrekonstruksi atau menyusun kembali strategi gerakan misi dan komunikasi Kristen pasca pandemi Covid19 ? Persoalan ini secara otomatis menjadi tantangan yang harus disikapi dengan bijak, sekaligus peluang yang harus ditangkap dengan baik sehingga gereja dapat konsisten

\footnotetext{
${ }^{1}$ Rosamond Rhodes, "Justice and Guidance for the COVID-19 Pandemic," The American Journal of Bioethics 20, no. 7 (2020).

${ }^{2}$ Roedy Silitonga, "RESPON GEREJA ATAS PANDEMIK CORONAVIRUS DISEASE 2019 DAN IBADAH DI RUMAH,” Jurnal Manna Rafflesia 6, 2 (2020): 86-111.
} 
menjalankan tugas dan misinya di muka bumi. Hal tersebut menjadi tujuan penulisan karya ilmiah ini.

Sebelum menjawab persaolan di atas, maka perlu dimengerti secara jelas, bahwa keberlangsungan dan konsistensi gereja dalam melaksanakan misinya di sepanjang masa, sangat bergantung kepada pemahaman gereja akan jati diri, panggilan dan tugas yang diembannya sebagai "kawan sekerja Allah" yang diutus bekerja di ladang-Nya (1 Korintus 3:9). Kebenaran ini tentunya sangat bergantung sejauh mana gereja memahami teologi dan tugas misi sebagai prinsip dasar dan sekaligus motivasi penggerak yang dipakai Roh Kudus dalam melaksanakan misi Allah menyelamatkan dunia ini (Roma 1:16).

Perlu dipahami bahwa persoalan tentang arti, konteks dan dimensi misi sudah menjadi subjek yang kerap diselidiki dan diperdebatkan di kalangan para ahli misi, praktisi misi dan teolog. Paradigma, penafsiran dan praktek misi juga sudah mengalami pergeseran (shifting), tidak hanya di luar tapi juga dari dalam kekristenan sendiri. Pada prinsipnya, gereja dipanggil kembali untuk melakukan misi Allah di dunia. Oleh karena itu, harmoni antara teologi misi dan perspektif tentang tugas misi harus dimulai dengan Tuhan, yang bekerja terutama melalui gereja untuk menjangkau dan mengubah dunia. Teologi semestinya bertujuan membuat iman dapat dipahami dan konsisten dengan kenyataan. ${ }^{3}$ Oleh sebab itu, teologi misi harus bersifat ortopraksis. Dengan demikian dapat dipastikan bahwa tugas misi gereja adalah mentransformasi dunia dengan menjadi agen perubahan yang menjawab semua persoalan yang dihadapi oleh manusia di sepanjang masa. Hasil akhirnya ialah mendatangkan kemerdekaan, kedamaian dan keadilan bagi kebaikan ciptaan Allah. ${ }^{4}$ Sejalan dengan pemahaman akan teologi dan tugas misi yang telah dijelaskan di atas, maka seyogyanya teologi misi terautentikasi dalam kerangka pemikiran teologis berupa konsep Missio Dei, Missio Christo dan Missio Ecclesiae (selanjutnya akan dipakai dengan istilah 3M).

Pertama, Sejarah pemikiran dan perkembangan pemakaian istilah Missio Dei. Kerangka pemikiran teologis tentang Missio Dei dapat ditelusuri kembali, mulai dari Augustinus yang mengusung konsep aktivitas Allah Tritunggal (Truine God) yang mengutus Sang Anak, dan Sang Anak mengutus Roh Kudus untuk melakukan tugas misi, konsep pemikiran teologis ini dipakai oleh Thomas Aquinas dengan istilah Missio Dei. Kemudian Karl Barth mencetuskan bahwa misi adalah pekerjaan Allah dan kesejatian misi gereja harus merupakan respon dari misi Allah (God's Mission). Selanjutnya, gagasan ini dipakai oleh Hartenstein untuk membedakannya dari Missio Ecclesiae atau misi gereja. Istilah Missio Dei kemudian disempurnakan dalam pertemuan International Missionary Council tahun 1952 di Wilinggen. Apa yang dimaksud dengan Missio Dei ialah kerangka teologis yang menegaskan bahwa misi adalah Misi Allah, gereja tidak memiliki misinya sendiri. Misi Allah berkaitan

\footnotetext{
${ }^{3}$ Canon B. Shambare and Selaelo T. Kgatia, "Church, Mission and Reconstruction: Being a Church with Integrity in Reconstruction Discourse in Post-Colonial Zimbabwe," HTS Teologiese Studies Journal 74, 1 (2018).

${ }^{4}$ D.J. Bosch, Transforming Mission: Paradigm Shifts in Theology of Mission (Maryknoll, New York: Orbis Books, 1991).
} 
dengan tugas penebusan dunia yang dikerjakan oleh Allah Tritunggal dan gereja berpartisipasi dalam misi ini. Missio Dei dalam penelitian Flett, dalam kaitannya dengan aktifitas Tirtunggal, menjadikan orang percaya sebagai sebuah missionary community atau komunitas misionaris. ${ }^{5}$ Di sini, misi Allah yang dijalankan oleh orang-orang percaya, dipahami sebagai pernyataan karakter, aktifitas dan karya Allah Tritunggal (The Truine God) yang membawa kesejahteraan bagi dunia ciptaan-Nya, baik dalam bidang spiritual, sosial dan ekonomi, Penekanannya bukan pada aspek ekklesiologi atau soteriologi, melainkan hal ini menyangkut Kerajaan Allah, gereja, penganut agama lain atau bangsa-bangsa, dan penginjilan. ${ }^{6}$ Misi terletak pada inti teologi dalam karakter dan tindakan Tuhan itu sendiri dan menjadi titik temu iman dan strategi. ${ }^{7}$

Kedua, Missio Christos atau Misi Kristus. Apa yang dilakukan Kristus ketika berinkarnasi ke dalam dunia ini sejalan dengan apa yang dipahami dalam Missio Dei. Tuhan Yesus menyelesaikan dan menjawab semua persoalan manusia yang mendasar baik itu berkatian dengan bidang spiritual, sosia dan ekonomi. Ia membebaskan orang-orang berdosa dari belenggu Setan dan menyembuhkan orang-orang sakit (Matius 4:23; Lukas 6:17-19), memberi makan orang banyak (Matius 14:13-21; Markus 6:30; Lukas 9:10-17; Yohanes 6:113) sebagai tanda bahwa Kerajaan Allah telah datang dan didemontrasikan oleh-Nya (Matius 12:28; Lukas 11:20). Melalui kematian-Nya di atas kayu salib, Kristus memulai rencana penebusan Allah yang kekal dan mendamaikan dunia dengan Allah melalui pengorbanan-Nya (Yohanes 3:16; Roma 5:8-9; 2 Korintus 5:19, 21). Di sini, misi bersifat kristosentris dan kosmosentris, artinya penebusan berpusat pada karya Kristus di Golgota dan bagi isi dunia (kosmos) ini. Selain itu, melalui pelayanan Kristus pula, terlihat bahwa Allah menyatakan sikap solider artinya senasib, sepenanggungan atau setia kawan, ${ }^{8}$ dengan manusia yang menderita akibat berbagai persoalan hidup. Di sini dapat dipahami bahwa Misi Kristus bersifat utuh (holistik). Maksudnya Allah ikut merasakan penderitaan manusia seutuhnya dengan cara Allah ikut menderita bersama dan bagi manusia melalui penderitaan Yesus Kristus. ${ }^{9}$ Dapat disimpulkan, Missio Christo bersifat Kristosentris, Kosmosentris dan Holistik.

Ketiga, setelah Hari Pentakosta (KPR.2) yakni pencurahan Roh Kudus bagi gereja, maka tugas misi Kristus, dialihkan kepada gereja (Ekklesia). Tuhan Yesus berkata bahwa gereja akan diberi kuasa untuk menjadi saksi-Nya, mulai dari Yerusalem, Yudea, Samaria dan sampai ke ujung bumi (KPR. 1:8). Inilah Missio Ecclesiae, yaitu tugas misi yang dijalankan

\footnotetext{
${ }^{5}$ John G. Flett, "Missio Dei: A Trinitarian Envisioning of a Non-Trinitarian Theme," Missiology: An International Review 37, 1 (2009): 5-18.

${ }^{6}$ Eddie Arthur, "Missio Dei and the Mission of the Church," Wycliffe Global Alliance, 2013, https://static1.squarespace.com/static/56dee43ee321400514f98522/t/575c31a8e32140042bb2b7bb/14656598168 91/3+MISS+301+Mag+3.pdf.

${ }^{7}$ William A. Dyrness, Let The Earth Rejoice! A Biblical Theology of Holistic Mission (Eugene, Oregon: Wipf \& Stock Publishers, 1991), 11.

${ }^{8}$ Badan Pengembangan dan Pembinaan Bahasa, Kemendikbud, “KBBI Daring Kemendikbud,” Solider (Jakarta, 2016).

"Sonny Eli Zaluchu, "Penderitaan Kristus Sebagai Wujud Solidaritas Allah Kepada Manusia," Jurnal Dunamis 2, 1 (Oktober 2017): 61-74.
} 
oleh gereja. Yang bermula dari para Rasul dan seterusnya kepada jemaat mula-mula dan gereja di sepangjang masa. Otoritas dan visi penginjilan gereja sepenuhnya dimulai dan digerakkan oleh Roh Kudus yang merupakan bagian tidak terpisahkan dari aktifitas Allah Tritunggal dalam menyelamatkan dunia. Dengan demikian, kerangka pemikiran Missio Ecclesiae sejalan dengan Missio Dei dan Missio Christos bahwa misi adalah pekerjaan atau misi Allah (God's Mission). Dalam kerangka pemikiran teologis Missio Dei, gereja terpanggil menjadi kawan sekerja Allah untuk membawa kedamaian, keadilan dan kesehateraan bagi bangsa-bangsa. Seiring dengan kerangka teologis Missio Christos, gereja terpanggil untuk melaksanakan Amanat Agung (Matius 28:19-20) dengan kuasa Roh Kudus, dimana gereja dipanggil untuk menjadi wakil Kristus di dunia untuk memberikan dampak signifikan berupa transformasi spiritual, sosial dan ekonomi. Untuk itu, gereja harus menghindari sikap eksklusif dan intoleran, jika ingin memenangkan sebanyak mungkin orang bagi Kristus di tengah pluratis agama dan budaya manusia yang ada di dunia.

Selain itu, gereja dipanggil untuk melaksanakan misi kemanusiaan secara aktif dan konkrit termasuk dalam usaha-usaha pembangunan. Di sini, misi gereja harus kontekstual dengan memperhatikan isu-isu global yang berkembang di masyarakat dunia terutama yang mengancam keberlangsungan kehidupan manusia dan planet bumi ${ }^{10}$, misalnya ancaman pandemi Covid-19 yang sedang melanda planet ini, termasuk isu-isu kemiskinan, ekonomi dan politik, serta kerusakan alam. ${ }^{11}$ Dapat disimpulkan, Missio Ecclesiae atau misi gereja, dalam merespon panggilan dan tugasnya menjalankan misi Allah bagi dunia, harus berciri non-eksklusif, toleran, dan kontekstual.

Teologi misi sebenarnya menyajikan hal-hal berupa prinsip dan gagasan yang melandasi sebuah gerakan misi dan komunikasi Kristen. Yang terakhir disebut ini maksudnya adalah kesaksian Kristen, dimana orang-orang percaya dapat mengomunikasikan kesaksian hidup dan imannya kepada publik atau masyarakat. Tentunya keduanya berkaitan erat. Gerakan misi dimaknai sebagai upaya para misionaris yang tergabung dalam berbagai lembaga misi lokal, nasional maupun internasional termasuk para praktisi misi di gerejagereja lokal dalam melaksanakan Amanat Agung Kristus. Sejalan dengan itu, setiap orang percaya juga diharapkan menjadi saksi Kristus yang hidup dengan cara mengomunikasikan iman dan kesaksian hidupnya kepada orang banyak. Kedua pihak memainkan tugas yang sama, meski dengan bobot dan urgensi tanggungjawab yang berbeda satu sama lain. Namun, dalam upaya menjawab tantangan era digital dan adaptasi kebiasaan baru akibat pandemi Covid-19, maka komunikasi Kristen menjadi sebuah strategi misi yang penting dan diharapkan mampu membawa berita Injil lebih masif disebarluaskan lewat berbagai media sosial yang marak perkembangannya saat ini.

\footnotetext{
${ }^{10}$ Os Guinness, Renaisans (Malang: Literatur SAAT, 2017).

${ }^{11}$ Yohanes H. Tampubolon, "Misi Gereja Di Era Kapitalisme Global: Eksplorasi Pelayanan Misi Yesus," Jurnal Societas Dei 7, 2 (2020): 197-217.
} 


\section{Metode}

Metode yang digunakan dalam penulisan karya ilmiah ini adalah metode studi literatur Kajian pustaka dilakukan dengan cara melakukan analisis terhadap teks-teks alkitab, jurnal penelitian, buku-buku yang membahas dan membicarakan isu-isu terkait dengan pandemi covid-19 dan teologi misi berupa kerangka pemikiran teologis Missio Dei, Missio Christos, dan Missio Ecclesiae serta implikasinya bagi tugas misi. Kemudian melakukan sintesis berdasarkan kaidah-kaidah ilmiah untuk menjawab masalah penelitian yaitu menggagas sebuah strategi bagi gerakan misi dan komunikasi Kristen yang relevan pasca pandemic Covid-19 berdasarkan hakekat teologi misi. Hasil kajian dalam karya ilmiah ini dengan sendirinya merupakan sebuah Scientific Literature Review.

\section{Hasil dan Pembahasan}

Berdasarkan kajian tentang kerangka pemikiran teologis tentang teologi mis sebagaimana telah diuraikan di atas, berikut peneliti menemukan paling sedikit ada tiga hal yang menjadi sumbangsih teologi misi bagi gerakan misi dan komunikasi Kristen pasca pandemi Covid-19 yaitu:

Pertama, baik lembaga pelayanan misi, gereja secara lembaga maupun orang-orang Kristen secara individual harus tanggap terhadap isu-isu kemanusiaan global yang berkembang saat ini. Isu seperti ketidakadilan sosial, kesehatan, ekonomi, pendidikan dan pembangunan bangsa sudah semestinya menjadi perhatian semua orang percaya jika ingin terlibat sebagai agen perubahan dalam mewujudkan rencana dan misi Allah bagi dunia. Terutama dalam menyikapi adaptasi kebiasaan baru akibat pandemi Covid-19, gereja perlu memberikan apresiasi terhadap nilai-nilai kemanusiaan yang lebih besar. Seiring dengan hal ini, maka isu-isu berkaitan dengan hak Asasi Manusia (HAM), tidak terelakkan untuk dicermati dan dikritisi secara bijak tanpa mengorbankan, mereduksi dan mendistorsi kebenaran firman Allah yang kudus dan kekal itu. Perhatian terhadap nilai-nilai kemanusiaan juga perlu diperhatikan berkaitan dengan kerusakan alam yang mendatangkan bahaya bagi manusia, termasuk bencana alam (Narural Disasters). Oleh sebab itu, maka gereja perlu terlibat aktif menjalankan aksi kemanusiaan. ${ }^{12}$ Meski terkesan seolah-oleh gereja mengabaikan pemberitaan injil secara verbal, namun perlu dipahami bahwa penerapan teologi misi 3M tidak bersifat eksklusif dan intoleran saja, tetapi juga bersifat holistik, dalam arti menjawab semua persoalan hidup manusia baik spiritual, sosial dan ekonomi sebagai bagian integral dari visi gereja berdasarkan perjanjian Allah atau kovenan Allah ${ }^{13}$, juga sebagai perwujudan keadilan sosial dalam konteks penerapan Missio Dei. ${ }^{14}$ Berkenaan dengan

\footnotetext{
${ }^{12}$ Fredy Siagian, "REKONSTRUKSI MISI GEREJA DI ABAD 21," Jurnal Syntax Literate 1, 4 (2016): 1-13.

${ }^{13}$ Yakob Tomatala, "Gereja Yang Visioner Dan Misioner Di Tengah Dunia Yang Berubah,” Jurnal Teologi Integritas 2, 2 (2020): 131.

${ }^{14}$ Piter Randan Bua, David Samiyono, and Tony Christian Tampake, "Misi Gereja Dalam Mewujudkan Keadilan Sosial: Sebuah Perspektif Dari Sila Kelima Pancasila,” Jurnal Kurios 5, 2 (2019): 115.
} 
pandemi covid-19, maka penelitian Deguma dan rekan sebagaiaman dikutip Widjaya dkk, membingkai pandemi corona sebagai persoalan sosial yang harus disikapi oleh gereja. ${ }^{15}$

Kedua, Misi Allah bersifat kosmosentrik, dimana sasarannya adalah menebus semua bangsa di muka bumi. Perjumpaan berita Injil dengan beragam agama dan keyakinan tidak terelakkan. Dalam konteks wahyu umum, semua suku bangsa, bahasa dan kaum di muka bumi ini memiliki Sensus Divinitas (kesadaran Ilahi) akan keberadaan Tuhan. Dalam perspektif ini, maka Injil semestinya diberitakan dengan sikap yang terbuka kepada perbedaan, toleran kepada pluralitas agama-agama di dunia. Terutama di negara-negara Asia dimana kemajemukan suku, bahasa dan agama sangat besar, bila dibandingkan dengan negara-negara Eropah. Menghadapi kondisi ini, maka dialog antar pemeluk agama yang berbeda menjadi sebuah peluang yang terbuka luas. Era global membawa suatu kesadaran baru bagi umat manusia, bahwa mereka tidak lagi harus menutup diri kepada kemajuan ilmu pengetahuan dan teknologi, termasuk dalam hal beragama. Dalam konteks Indonesia, hal ini bagian dari potensi demografis Indonesia, menduduki rangking empat dunia setelah China, India, dan Amerika Serikat menurut World Economic Forum, dimana keragaman agama menjadi sumber daya sosial-budaya yang ikut diperhitungkan sebagai aset bagi kemajuan bangsa. ${ }^{16}$ Ini menjadi kesempatan (kairos) bagi gereja untuk berinisiatif melakukan dialog keagamaan.

Apalagi ditunjang dengan kemajuan teknologi informasi dan telekomunikasi dan adaptasi kebiasaan baru akibat pandemi Covid-19 membuka peluang dan kesempatan serta sarana efektif yang bisa dipakai oleh gereja dan lembaga pelayanan misi untuk berdialog dengan pemeluk agama-agama lain dalam menjalankan misi kemanusiaan dan mencerdaskan kehidupan bangsa. Berkaitan dengan dialog atau menjalin komunikasi dengan pemeluk agama lain maka metode yang bisa dipakai adalah Metode Partikularis-Transformatif yaitu sikap menghayati nilai-nilai kekristenan di satu sisi, namun tetap menghargai orang yang berbeda keyakinan sebagai sesama makhluk ciptaan Allah di sisi lainnya, dimana perbedaan keyakinan merupakan kedaulatan Allah, olehnya gereja ikut menuntaskan persoalan kemanusiaan melalui dialog terbuka dan konstruktif dengan tetap menjunjung hak asasi orang lain. ${ }^{17}$ Selain itu, orang-orang percaya juga semestinya mengusahakan persahabatan sesama pemeluk agama lain, khusus di dalam konteks kemajemukan masyarakat Indonesia dengan beragam keyakinan, suku, bahasa dan budaya, termasuk masyarakat Asia yang majemuk. ${ }^{18}$ Peran agama dalam negara Pancasila terwujud dalam sikap Unity in Diversity (Kesatuan Dalam Keragaman) terkandung dalam tulisan Bhinneka Tunggal Ika yang dicengkeram kaki

\footnotetext{
${ }^{15}$ Fransiskus Irwan Widjaja et al., "MenstimulasiPraktikGereja Rumah Di Tengah Pandemi Covid-19," Jurnal Kurios 6, 1 (2020): 127-139.

${ }^{16}$ Amat Mukhadis, "SOSOK MANUSIA INDONESIA UNGGUL DAN BERKARAKTER DALAM BIDANG TEKNOLOGI SEBAGAI TUNTUTAN HIDUP DI ERA GLOBALISASI," Jurnal Pendidikan Karakter 2 (2013): 118-119.

${ }^{17}$ Daniel Ronda, "PERAN KEPEMIMPINAN KRISTEN MEMBANGUNDIALOG ANTAR UMAT UMAT BERAGAMA" 2, 2 (2019): 47-54.

${ }^{18}$ Yohanes Krismantyo Susanta, “"Menjadi Sesama Manusia' Persahabatan Sebagai Tema Teologis Dan Implikasinya Bagi Kehidupan Bergereja," Jurnal Dunamis 2, 2 (2018): 103-118.
} 
Burung Garuda, lambang negara Republik Indonesia, harus dimiliki oleh setiap pemeluk agama dalam menjalankan perannya di bumi Nusantara. ${ }^{19}$ Hal ini seiirng dengan misi Allah melalui Kristus untuk menjadikan semua bangsa murid-Nya (Matius 28:19-20).

Ketiga, gereja sangat perlu dan sudah saatnya memanfaatkan media sosial sebagai sarana memberitakan Kabar Baik (Euanggelion), baik itu melalui Facebook, Mesengger, Whatsapp, Instagram, YouTube, Google+, dll. Masyarakat dunia di era global ini menjadi masyarakat virtual atau masyarakat cyber yang tenggelem dalam arus ekstasi komunikasi (Party-Line), dimana jaringan komunikasi virtual yang transparan mampu melenyapkan kategori, batas dan hierarki sosial serta mendobrak batas-batas nilai dan ukuran moral. ${ }^{20}$ Komunikasi menjadi masif lewat jejaring sosial. Terutama komunikasi interpersonal (antar pribadi). Komunikasi interpersonal berfungsi membangun hubungan (relationship) antar pribadi dan berguna untuk menemukan jawaban dari persoalan yang dipercakapan. ${ }^{21}$ Oleh karena itu, para pengikut Kristus perlu membaca dan memahami tanda zaman. Ini sekaligus menjadi sebuah situasi yang mendesak dimana gereja semestinya sudah berselancar di tengah tingginya gelombang komunikasi virtual yang terjadi masa kini. Tujuannya jelas, yaitu menyampaikan dan menyebarkan berita Kabaik baik tentang karya penebusan Kristus bagi dunia sejalan dengan misi Allah (God's Mission). Penyampaian Kabar Baik bisa dilakukan melalui situs-situs Web dan berbagai media sosial yang telah disinggung di atas. Demikian pula, program-program pelayanan gereja juga semestinya dapat dilakukan secara daring, baik itu berupa Webinar, Workshop, Conference, Seminar, Worship, Prayer Conference, Sunday Service, dll. Melalui itu semua, gereja ikut serta menggarami dan menerangi masyarakat cyber yang telah menjelma menjadi mesin penyedot dan lumpur isap yang menarik tidak sedikit manusia maya dalam jurang amoralitas yang membinasakan. Tentunya dengan harapan agar masyarakat dunia global tanpa Kristus yang sedang menuju kebinasaan saat ini, dapat menemukan terang untuk kembali ke jalan yang benar dan menemukan Jurselamat yang telah mati menyelamatkannya.

\section{Kesimpulan}

Teologi misi berupa kerangka teologis Missio Dei, Missio Christos, dan Missio Ecclesiae menjadi dasar pemikiran yang semestinya memotivasi gereja untuk memikirkan kembali dan menyusun ulang (Rethingking and Recontructing) strategi gerakan misi dan komunikasi Kristen pasca pandemi Covid-19 yaitu dengan cara menempatkan dirinya sebagai partisipan yang menjalankan misi Allah (God-s Mission) yaitu menebus dunia ciptaan-Nya dari kebinasaan akibat dosa. Melihat konteks masyarakat virtual dan dampak adapatasi kebiasaan baru di Era New Normal (pasca pandemi Covid-19) yang sangat komunikatif, toleran dan terikat secara global baik dari sisi kemanusian dan penggunaan teknologi, namun

\footnotetext{
${ }^{19}$ N.K. Atmadja Hadinoto, Dialog Dan Edukasi, 12th ed. (Jakarta: BPK Gunung Mulia, 2012), 35.

${ }^{20}$ Errika Dwi Setya Watie, “Komunikasi Dan Media Sosial,” Jurnal The Mesengger 3, 2 (2011): 71.

${ }^{21}$ Arief Fajar, "The Relationship; Kunci Relasi Dalam InterpersonalContext (Pemetaan Tradisi Teori Komunikasi Mengenai Komunikasi Interpersonal Dalam Pandangan Stephen W. Littlejohn)," Jurnal Komuniti V, 1 (2013): 24.
} 
sudah dirusak oleh pergeseran nilai sosial dan moral yang masif, maka gereja sangat perlu meresponi isu-isu kemanusiaan global dengan mengadakan pelayanan yang berisfat holistik, memikirkan upaya berdialog dengan sesama penganut agama lain, dan memanfaatkan media sosial dan komunikasi virtual sebagai sarana mengomunikasikan Injil secara gamblang dan terbuka dilandasi sikap non-ekslusif, namun tetap teguh meyakini kuasa Injil Kristus yang mampu menyelamatkan manusia dari kuasa dosa.

\section{Rujukan}

Arthur, Eddie. "Missio Dei and the Mission of the Church." Wycliffe Global Alliance, 2013. https://static1.squarespace.com/static/56dee43ee321400514f98522/t/575c31a8e32140 042bb2b7bb/1465659816891/3+MISS+301+Mag+3.pdf.

Badan Pengembangan dan Pembinaan Bahasa, Kemendikbud. "KBBI Daring Kemendikbud." Solider. Jakarta, 2016.

Bosch, D.J. Transforming Mission: Paradigm Shifts in Theology of Mission. Maryknoll, New York: Orbis Books, 1991.

Bua, Piter Randan, David Samiyono, and Tony Christian Tampake. "Misi Gereja Dalam Mewujudkan Keadilan Sosial: Sebuah Perspektif Dari Sila Kelima Pancasila.” Jurnal Kurios 5. 2 (2019): 109-214.

Dyrness, William A. Let The Earth Rejoice! A Biblical Theology of Holistic Mission. Eugene, Oregon: Wipf \& Stock Publishers, 1991.

Fajar, Arief. "The Relationship; Kunci Relasi Dalam InterpersonalContext (Pemetaan Tradisi Teori Komunikasi Mengenai Komunikasi Interpersonal Dalam Pandangan Stephen W. Littlejohn).” Jurnal Komuniti V. 1 (2013): 24-30.

Flett, John G. "Missio Dei: A Trinitarian Envisioning of a Non-Trinitarian Theme." Missiology: An International Review 37. 1 (2009): 5-18.

Guinness, Os. Renaisans. Malang: Literatur SAAT, 2017.

Hadinoto, N.K. Atmadja. Dialog Dan Edukasi. 12th ed. Jakarta: BPK Gunung Mulia, 2012. Mukhadis, Amat. "SOSOK MANUSIA INDONESIA UNGGUL DAN BERKARAKTER DALAM BIDANG TEKNOLOGI SEBAGAI TUNTUTAN HIDUP DI ERA GLOBALISASI.” Jurnal Pendidikan Karakter 2 (2013): 115-136.

Rhodes, Rosamond. "Justice and Guidance for the COVID-19 Pandemic." The American Journal of Bioethics 20, no. 7 (2020).

Ronda, Daniel. "PERAN KEPEMIMPINAN KRISTEN MEMBANGUNDIALOG ANTAR UMAT UMAT BERAGAMA" 2. 2 (2019): 47-54.

Shambare, Canon B., and Selaelo T. Kgatia. "Church, Mission and Reconstruction: Being a Church with Integrity in Reconstruction Discourse in Post-Colonial Zimbabwe.” HTS Teologiese Studies Journal 74. 1 (2018).

Siagian, Fredy. "REKONSTRUKSI MISI GEREJA DI ABAD 21." Jurnal Syntax Literate 1. 4 (2016): 1-13. 
Silitonga, Roedy. "RESPON GEREJA ATAS PANDEMIK CORONAVIRUS DISEASE 2019 DAN IBADAH DI RUMAH.” Jurnal Manna Rafflesia 6. 2 (2020): 86-111.

Susanta, Yohanes Krismantyo. “Menjadi Sesama Manusia' Persahabatan Sebagai Tema Teologis Dan Implikasinya Bagi Kehidupan Bergereja.” Jurnal Dunamis 2.2 (2018): 103-118.

Tampubolon, Yohanes H. "Misi Gereja Di Era Kapitalisme Global: Eksplorasi Pelayanan Misi Yesus.” Jurnal Societas Dei 7. 2 (2020): 197-217.

Tomatala, Yakob. "Gereja Yang Visioner Dan Misioner Di Tengah Dunia Yang Berubah." Jurnal Teologi Integritas 2. 2 (2020): 127-139.

Watie, Errika Dwi Setya. "Komunikasi Dan Media Sosial." Jurnal The Mesengger 3. 2 (2011): 69-75.

Widjaja, Fransiskus Irwan, Candra Gunawan Marisi, Togatorop T. Mangiring Tua, and Handreas Hartono. "MenstimulasiPraktikGereja Rumah Di Tengah Pandemi Covid19.” Jurnal Kurios 6. 1 (2020): 127-139.

Zaluchu, Sonny Eli. "Penderitaan Kristus Sebagai Wujud Solidaritas Allah Kepada Manusia." Jurnal Dunamis 2. 1 (Oktober 2017): 61-74. 